PRZEGLĄD NAUK HISTORYCZNYCH 2016, R. XV, NR 2

http://dx.doi.org/10.18778/1644-857X.15.02.10

PASQuale Fornaro

Uniwersytet w Mesynie

\title{
Włoskie Risorgimento: mit i rzeczywistość
}

\section{Podstawowe pytanie: czy Włochy są naprawdę jednym państwem, czy istnieje wiele Wloch?}

$\mathrm{R}$

ozpoczynając temat mitu i rzeczywistości włoskiego Risorgimento, chciałbym od razu wprowadzić element nieodzowny do

zwiazanego z zagadnieniem problemu. Chodzi o kwestie faktycznej jedności Włoch, ich jednorodności politycznej, społecznej, kulturowej, gospodarczej. Jest ona o tyle istotna, że mówi się o niej już od momentu utworzenia zjednoczonego państwa włoskiego (1861), a także dlatego, że co jakiś czas, przede wszystkim w ostatnich 25 latach (od kryzysu i końca tzw. pierwszej republiki w latach 1992-1994) ${ }^{1}$, powraca ona do dyskusji w zwyczajowym pytaniu: czy w sytuacji formalnej jedności można mówić o jednych Włoszech, czy może istnieje ich więcej? Kwestia rzeczywistego zjednoczenia

1 W rzeczywistości nie chodzi o prawdziwą cezurę instytucjonalna, usankcjonowana przez zmiany strukturalne w konstytucji, ale o radykalna zmianę na scenie politycznej, wymuszoną w znacznej mierze przez serię skandali, w które zaangażowana była duża część ówczesnej klasy rządzącej, a także o późniejsze umocnienie się nowych ugrupowań politycznych, takich jak Forza Italia i Liga Północna, również wskutek wprowadzenia reformy wyborczej, która wyznaczała przejście od czystego systemu proporcjonalnego na rzecz systemu większościowego. W ten sposób zniknęły „historyczne”, stare partie, które zdominowały politykę Włoch po II wojnie światowej (Chrześcijańska Demokracja oraz partie komunistyczna, socjalistyczna, socjaldemokratyczna, republikańska, liberalna itp.) i rozpoczął się nowy, kontrowersyjny okres w polityce. Informacje na ten temat znaleźć można m.in. w: A. Le pre, Storia della Prima repubblica. L'Italia dal 1943 al 2003, Bologna 2006, w szczególności s. 315. 
Włoch to problem stary, szeroko komentowany i od samego początku uwarunkowany mnóstwem stereotypów. Wśród nich znajdujemy różnice antropologiczno-kulturowe między Włochami z Północy i Południa, między „polentoni” a „terroni”, jak często Włosi określają siebie nawzajem $\mathrm{w}$ pejoratywnym tonie ${ }^{2}$, które przekroczyły granice narodowe i sa w jakimś stopniu znane także za granicą.

Oczywiście na poziomie prawa konstytucyjnego nie stawia się nawet takiego pytania: Włochy sa rzeczywiście jedne ${ }^{3}$. Jednakże w codziennej rzeczywistości pytanie to - jak zostało powiedziane - jest bardziej złożone i przez półtora wieku zjednoczonego państwa podlegało ocenie i krytyce, a każda $z$ nich mogła zostać w jakiś sposób uzasadniona, poparta mniej lub bardziej wiarygodnym powodem.

Jak dobrze wiedzą ci, którzy zajmują się współczesną włoską historia i nie tylko, jako pierwsi zdali sobie sprawę $z$ tego problemu zaraz po proklamowaniu zjednoczenia (17 marca 1861 r.) niektórzy spośród wielkich bohaterów narodowego Risorgimento. Wystarczy wspomnieć Massima d'Azeglia ${ }^{4}$, krytycznego zwolennika dopiero co zakończonego zjednoczenia, odwołując się do jego sławnego stwierdzenia: „Stworzyliśmy Włochy, teraz trzeba stworzyć Włochów”.

2 Jako „polentone”, termin, który w znaczeniu dosłownym służył do wskazania ludzi, którzy jedli głównie polentę (podstawowy posiłek biednej kuchni Włoch północnych jeszcze w pierwszych dziesięcioleciach XX w.), określa się ogólnie mieszkańca Włoch północnych; epitetem „terrone” natomiast, wskazujacym dosłownie kogoś, kto pracuje na roli, określa się mieszkańców Włoch południowych. Oba terminy, używane przez obie strony w przeszłości w celu podkreślenia rzekomej niższości etnicznej i kulturowej przeciwnej strony, $z$ biegiem lat utraciły silnie pejoratywne znaczenie, tak że obecnie stosowane sa przeważnie w sposób humorystyczny, a nawet autoironiczny.

${ }^{3}$ Artykuł 5 konstytucji (która weszła w życie 1 I 1948 r.) brzmi następująco: „Republika jednolita i niepodzielna uznaje i wspiera samorząd lokalny; urzeczywistnia w działalności służb podlegających państwu najszerszą decentralizację administracji; dostosowuje zasady i system swojego ustawodawstwa do wymagań samorząu i decentralizacji" [kursywa autora].

${ }^{4}$ Massimo d'Azeglio (1798-1866), liberalny polityk piemoncki, a także wszechstronny artysta i literat, stał na czele rzadu Królestwa Piemontu od 1849 do 1852 r., w szczególnie trudnym dla Piemontu okresie $z$ powodu klęski w wojnie z Austria w latach 1848-1849. Wśród wielu poświęconych mu studiów należy wskazać przede wszystkim publikację M. Brignoliego, Massimo d'Azeglio. Una biografia politica, Milano 1988.

5 Zdanie to $w$ rzeczywistości nigdy nie zostało przez Massima d’Azeglia wypowiedziane, a przynajmniej nie w takiej formie. Jest to pośmiertna, mniej lub bardziej wierna przypuszczalnemu oryginałowi, dokonana przez pisarza, parlamentarzysty wielu kadencji i ministra Królestwa, Ferdinanda Martiniego, 
Zdanie to było niezwykle popularne w póżniejszych dyskusjach politycznych, toczonych w przeszłości i dziś wśród zwolenników i przeciwników zjednoczonych Włoch. Było bardzo często cytowane, nawet nadużywane, by pokazać, jak słabo zakorzeniona i rozpowszechniona była świadomość narodowa Włochów i jak liczne były wady obywateli tego kraju, przede wszystkim w zależności od ich pochodzenia geograficznego (północ i południe kraju).

Jednak prawdziwy problem, poza zacytowanym przed chwila zdaniem, został bardzo dobrze ujęty w następujacych proroczych słowach ze Wspomnień tego samego d'Azeglia, opublikowanych tuż po jego śmierci w 1866 r.: „Włochy od niemal pół wieku walczą o to, by stać się jednym ludem i zostać uznane za naród. W znacznej części odzyskały swoje terytorium. Walka z obcym się zakończyła, ale nie to jest największa trudność. Największa, prawdziwą trudnościa [...] jest walka wewnętrzna. Najbardziej niebezpieczni wrogowie Włoch to nie Niemcy, a Włosi. Dlaczego? Dlatego że Włosi chcieli stworzyć nowe państwo włoskie, ale sami chcieli pozostać dawnymi Włochami [...], ze swoimi moralnymi słabościami, które ab antico były ich ruiną; dlatego że myślą o reformie Włoch, a żaden $z$ nich się nie spostrzegł, że aby to się udało, najpierw muszą sami się zreformować, dlatego że Włosi, jak wszystkie inne ludy, nie będą mogli stać się narodem, dopóki każdy z nich nie spełni własnego obowiązku [...]. Ale żeby spełnić własne obowiązki, potrzeba siły woli i przekonania, że obowiązek należy wypełnić nie dlatego, że przynosi radość lub korzyści, ale dlatego, że jest obowiązkiem; i ta właśnie siła woli [...] nazywa się jednym słowem: charakterem. [...] A niestety każdego dnia zmierzamy w odwrotnym kierunku" .

Według tego ważnego polityka $z$ Piemontu chodziło zatem o to, by porozumieć się w kwestii prawidłowego (i powszechnie podzielanego) sposobu pojmowania tożsamości narodowej, by współpracować i wspólnie budować nową rzeczywistość polityczno-instytucjonalną, przezwyciężając dawne, zakorzenione przywary poszczególnych miast i podziały kulturowe i geograficzne oraz wiele uprzedzeń i różnic, które w przeszłości naznaczały najczęściej negatywnie tak zróżnicowaną rzeczywistość polityczną, społeczną i gospodarczą

„transkrypcja” pewnego zdania, które d'Azeglio miał wypowiedzieć około $1859 \mathrm{r}$. Martini uznał, że należy je streścić w ten sposób wiele lat po fakcie. Dalsze informacje w tej kwestii por. Fare gli italiani. Scuola e cultura nell'Italia contemporanea, red. S. Soldani, G. Turi, t. I, Bologna 1993, s. 17.

${ }^{6}$ M. d'Azeglio, I miei ricordi, red. A.M. Ghisalberti, Torino 1949, s. 38. 
jak Włochy. To właśnie przeciwko tym „grzechom pierworodnym” występowali w poprzednich dziesięcioleciach wielcy „ojcowie duchowi” narodu, poeci tacy jak Vittorio Alfieri, Ugo Foscolo, Giovanni Berchet, Alessandro Manzoni i inni, czy myśliciele polityczni, jak Vincenzo Gioberti czy Giuseppe Mazzini. W romantycznym klimacie tamtych czasów wokół nich i ich dzieł szybko utworzył się niepodległościowy mit Włoch i włoskości, który jednak stawał się najczęściej ćwiczeniem retorycznym na użytek nielicznych intelektualistów, a nie prawdziwą doktryną polityczna i społeczna, powszechnie uznawana przez społeczeństwo ${ }^{7}$.

Niezaprzeczalnym faktem jest to, że w trakcie 155 lat wspólnego życia, przede wszystkim w okresach kryzysu, owa jedność często była postrzegana i osądzana w sposób bardzo krytyczny, w skrajnych przypadkach nawet jako błąd polityczny, wobec którego należałoby wreszcie zastosować remedium w postaci silnej autonomii politycznej i ekonomicznej, federacji, a nawet ponownego podziału. Innymi słowy, dziś jedność kraju nie stanowi dla niektórych środowisk zjawiska ustalonego i definitywnego, ale pozostaje nierozwiązanym problemem, otwartym na możliwe rozwiązania.

\section{Różne ideologie i strategie, wspólny cel: niepodległość}

Spróbujmy krótko prześledzić najważniejsze etapy, które historycznie charakteryzuja długi, kręty marsz Włoch ku niepodległości narodu i który poza „niepodległościowym mitem” jedności stworzył także sprzeczna rzeczywistość „narodu niedoskonałego”, jak często publicznie go określam (choć oczywiście nie jest to tylko moja opinia ${ }^{8}$ ). Dokonał się on, jak wiadomo, w wyniku trzy ważnych wojen: pierwszej, $z$ lat 1848-1849, zakończonej klęską zarówno $z$ pozycji federalistów-monarchistów (umiarkowanych liberałów), jak i demokratów i republikanów Mazziniego. Drugiej, zwycięskiej wojny z 1859 r., przeprowadzonej przez Królestwo Sardynii (Piemont) z pomocą Napoleona III, rok później zwieńczonej słynną wyprawa Garibaldiego, który na czele swoich „czerwonych koszul” wyzwolił

7 O narodzinach i upowszechnieniu się literatury patriotycznej dażącej do wzmocnienia poczucia przynależności do narodu por. A.M. Banti, La nazione del Risorgimento. Parentela, santità e onore alle origini dell'Italia unita, Torino 2000.

${ }^{8}$ Por. np. P. Fornaro, „Fatta l'Italia, bisogna fare gli italiani”. Elogio di una Nazione imperfetta, „Anuarul Institutului de studii italo-român” [Cluj-Napoca-Rzym] 2013, t. X, s. 259-279. 
południe Włoch od władzy burbońskiej, by natychmiast „podarować” je królowi Wiktorowi Emanuelowi II, umożliwiając mu w ten sposób ogłoszenie zrodzenia się zjednoczonego Królestwa Włoch. Trzecia wojna to konflikt austriacko-pruski z 1866 r., który doprowadził do aneksji Wenecji Euganejskiej. Przyłączenie Rzymu w 1870 r. i zdobycie Trydentu oraz Wenecji Julijskiej w roku 1918, czyli pod koniec I wojny światowej, dopełniły budowę terytorialna Italii.

Mimo wspólnego celu wyzwolenia Włoch $z$ bezpośredniego i pośredniego panowania Austrii strategie i programy poszczególnych prądów niepodległościowego ruchu włoskiego w tamtych latach były bardzo różne. Znowu trzeba podkreślić wielkie podziały historyczne kraju. Ujmując rzecz schematycznie: $z$ jednej strony stali liberałowie i umiarkowani monarchiści, którzy proponowali rozwiazania legitymistyczne i federacyjne (katolicy jednak opowiadali się za przewodnictwem papiestwa w federacji, podczas gdy filopiemontczycy aspirowali do federacji rzadzonej $z$ Turynu, a nie $z$ Rzymu ${ }^{9}$ ); $z$ drugiej strony stali demokratyczni republikanie, także podzieleni na federalistów (ich najbardziej wpływowym przywódca był Carlo Cattaneo ${ }^{10}$ i zwolenników zjednoczenia, działających pod zwierzchnictwem Giuseppe Mazziniego, postaci o niezaprzeczalnym znaczeniu na arenie międzynarodowej w sferze myśli demokratycznej i republikańskiej.

Jako komentarz (oraz wyjaśnienie) tych ostrych i $z$ pewnością nieprzynoszących dobrych efektów podziałów stanowiących dziewiętnastowieczną wersję średniowiecznego sporu między Gwelfami

${ }^{9}$ Wśród pierwszej grupy najważniejsza postacią był Vincenzo Gioberti (1801-1852), kapłan, filozof i polityk z Turynu, który w połowie lat czterdziestych opracował swój federalistyczno-umiarkowany program polityczny w słynnym piśmie Del primato morale e civile degli italiani, Capolago 1844. Gioberti stał także na czele rządu piemonckiego w trudnych miesiącach między pierwszą a druga fazą pierwszej wojny o niepodległość przeciwko Austrii (grudzień 1848 - luty 1849). Federalistyczny program filopiemoncki był popierany przez wielu umiarkowanych liberałów, takich jak Cesare Balbo (1789-1853), równie znaczacy polityk Królestwa Sardynii. Por. jego obszerny esej Delle speranze d'Italia, Capolago 1844.

10 Mediolańczyk Carlo Cattaneo (1801-1869), filozof o wykształceniu oświeceniowym i myśliciel polityczny, na którego duży wpływ wywarły idee pozytywizmu, był odważnym i nieprzejednanym zwolennikiem federalizmu republikańskiego, opartego na podstawach laickich i inspirowanego w pewnym stopniu konederacyjnym modelem szwajcarskim. Poza jego pismami teoretycznymi znaczaca była jego rola odegrana w rozpowszechnianiu współczesnej kultury laickiej na stronach „Il Politecnico”, miesięcznika „pogłębionych studiów ku dobrobytowi i społecznej kulturze", który założył w 1839 r. 
i Gibelinami należy wskazać, że wszystko to miało początek nie tylko w wielkich różnicach politycznych, lecz także, o czym dalej, w głębokiej nierówności strukturalnej między Włochami idealnymi (tymi wyśnionymi przez wspomnianych poetów i romantycznych myślicieli politycznych) oraz Włochami realnymi, ze wszystkimi swoimi wiekowymi i głęboko zakorzenionymi różnicami i specyficznymi cechami między poszczególnymi obszarami geograficznymi, językowymi, gospodarczymi i społecznymi. To właśnie był problem, który uwarunkował losy państw włoskich przed zjednoczeniem. Tylko nieliczne spośród nich zdały sobie $z$ niego sprawę $\mathrm{w}$ momencie, kiedy mimo tysięcy trudności urzeczywistniała się jedność kraju.

Bez wątpienia działo się tak $z$ winy ówczesnej klasy rządzącej, która mimo głosów krytycznych (np. ze strony cytowanego Carla Cattaneo) zablokowała jakiekolwiek sugestie decentralizacji administracyjnej, czyli „szacunku” dla silnych i trudnych do wykorzenienia cech regionalnych, w imię mocno scentralizowanego systemu, który w pierwszych 35-40 latach był przede wszystkim narzucony siła, za pomoca wszelkich sposobów: tych dobrych i tych złych (stany oblężenia, nadzwyczajne sądy wojskowe itd.). W toku przyszłej historii zjednoczonych Włoch wszystko to oznaczało serię odgórnych decyzji, strategicznych wyborów, np. w planie gospodarczym, które nie wszyscy popierali. Były one bowiem podejmowane tendencyjnie: na korzyść jednych obszarów i na niekorzyść innych. Włochy „liberalne” zatem zrodziły model polityczny i gospodarczy typu autorytarnego, mimo że formalnie był on oparty na podstawach konstytucyjnych i parlamentarnych, czyli miał stanowić reprezentację narodu ${ }^{11}$.

\section{„Zwycięzcy” i „pokonani” włoskiego Risorgimento: zjednoczenie czy aneksja?}

Urzeczywistnienie niepodległości narodowej i utworzenie państwa włoskiego stanowiło - co do tego sa zgodni niemal wszyscy historycy - zwycięstwo „aneksjonistów”, monarchistów i zwolenników Camilla Cavoura, którzy całkowicie wygrali tę ustrojową batalię.

\footnotetext{
11 Jako kartę konstytucyjną nowego zjednoczonego państwa Królestwo Włoch uzna Statut, który Karol Albert, władca Królestwa Sardynii, przyjął w 1848 r. Ta konstytucja utrzyma się, z koniecznymi modyfikacjami, aż do proklamowania republiki w 1946 r., kiedy zostanie spisana nowa republikańska karta konstytucyjna, która weszła w życie 1 I 1948 r. (por. przyp. 3).
} 
Zjednoczenie pod scentralizowaną kontrolą Turynu było triumfem niewatpliwego talentu dyplomatycznego politycznego geniusza, jakim był Cavour (układy $z$ Napoleonem III i doskonałe relacje $z$ Wielką Brytanią, ale także zdolność do kompromisu $z$ umiarkowanym skrzydłem ruchu republikańskiego $z$ Garibaldim na czele) ${ }^{12}$. Nie rozwiazało to jednak, ani nawet nie mogło rozwiąać, wymienionych wcześniej problemów, przede wszystkim lęków i uprzedzeń, które od samego początku, mimo terytorialnego i administracyjnego zjednoczenia, blokowały proces unifikacji ludności Półwyspu w celu stworzenia nowego podmiotu społecznego: „obywatela włoskiego”. Można przytaczać wiele przykładów, ograniczę się jednak do zacytowania tylko niektórych opinii i osądów ważnych polityków nowego państwa powołanych do zarządzania najdalszymi prowincjami dopiero proklamowanego Królestwa Włoch. Cytaty te pozwalają zrozumieć, że proces zjednoczenia narodowego był bardziej konkwista, niemal wojna typu kolonialnego, niż wojna ludu i spełnieniem wspólnej woli. Było to coś zupełnie odmiennego od mitycznego wyobrażenia, które chciała wpoić nam patriotyczna retoryka XIX i pierwszej połowy XX w. Należy zatem obiektywnie i trzeźwo ocenić tę kwestię, poddając krytycznej rewizji dużą część tego, co narodowa historiografia, przede wszystkim ta zwiąana $z$ liberałami i osoba Benedetta Crocego, stworzyła aż do okresu sprzed 70 lat w celu wyjaśnienia i usprawiedliwienia przyczyn i skutków włoskiego Risorgimento.

Wystarczy przeczytać ten krótki zbiór gorzkich komentarzy, wypowiedzianych już w pierwszych tygodniach po zjednoczeniu przez niektórych piemonckich (a w każdym razie północnych) „zwycięzców”,

${ }^{12}$ Camillo Benso, hrabia di Cavour (1810-1861), wybitna postać polityki piemonckiej lat pięćdziesiątych, najpierw minister rolnictwa i finansów, a później prezes Rady Ministrów; jest jednomyślnie uznawany za „architekta” zjednoczonych Włoch, których premierem był jednak tylko przez kilka miesięcy z powodu przedwczesnej śmierci w czerwcu $1861 \mathrm{r}$. Jego dzieło polityczno-dyplomatyczne po udziale Piemontu w wojnie krymskiej było bez watpienia wynikiem sekretnych układów $z$ Napoleonem III (Plombières, lipiec 1858 r.), na bazie których Francja miała wesprzeć (i tak rzeczywiście się stało) Królestwo Sardynii w nowej wojnie przeciw Austrii, jeżeli ta sprowokowałaby ją atakiem na niewielki Piemont. Późniejsze rozwiazanie narodowej kwestii włoskiej ma swoje źródła w umiejętności Cavoura znajdowania wpływowego sojusznika, który byłby w stanie przeciwstawić się potędze habsburskiej. Poza tym otrzymał także istotne wsparcie dyplomatyczne ze strony rząu w Londynie. Spośród licznych biografii poświęconych osobowości politycznej Cavoura ograniczymy się do wskazania najbardziej wyczerpujących, takich jak: H. He a rd er, Cavour, London-New York 1994; L. Ca fa g n a, Cavour, Bologna 1999. 
dopiero co oddelegowanych do południowych prowincji w celu przejęcia kontroli nad tamtejszą administracją, by zrozumieć, jak nieszczęśliwy los czekał te regiony południowe, które w całkowitej większości przyłączyły się do zjednoczenia z Królestwem Włoch po wyzwoleniu się $z$ wiekowego panowania burbońskiego. Słowa te sa jasnym wyrazem atawistycznego, nieprzezwyciężalnego poczucia niedowierzania i wrogości, niemal rasowej nienawiści: „Mój przyjacielu, co to sa za wsie? - pisze do Cavoura nadzwyczajny Komisarz prowincji neapolitańskich, rzymianin Luigi Carlo Farini - Co za barbarzyństwo! To nie sa Włochy! To jest Afryka: Beduini, w porównaniu do tych prostaków, są kwiatem cnót obywatelskich"13.

Także Diomede Pantaleoni, bliski współpracownik Cavoura, równie mocno podkreślał słabości Południa Włoch i wychwalał cnoty i wyższość ludzi z Północy: „Nasze połączenie $z$ Neapolem i wszystkimi prowincjami zakażonymi despotyzmem to już dla nas wystarczająca próba; ale możemy przynajmniej mieć nadzieję, że $z$ naszą siłą, $z$ naszą największą odwaga, $z$ naszym doświadczeniem i naszym charakterem uda nam się nimi rządzić i je oswoić"14. Nawet cytowany d'Azeglio przejawiał wielki strach, co widać w jednym $z$ jego prywatnych listów: „Obawiam się połączenia z Neapolitańczykami; to jakby położyć się do łóżka $z$ chorym na ospę!"15.

Piemontczyk Guido Borromeo, sekretarz generalny w Ministerstwie Spraw Wewnętrznych, dodał: „Potrzeba dwóch pokoleń, zanim tutaj [w Neapolu i na południu - przyp. P.F.] kradzież, kłamstwo i oszustwo zostana uznane za niedozwolone nie tylko przez Kodeks. Trzeba też, żeby ktoś przyjął na siebie rolę mistrza i pedagoga"16. Inny urzędnik państwowy, Tommaso Sorrentino, w pierwszych miesiącach 1861 r. pisał: „Włochy od Alp po Apeniny Rzymskie mają jedno życie, jeden sposób myślenia, jedna motywację; od Apenin do morza zaś drugie. Na Północy dominuje patriotyzm, na Południu interes; tu poświęcenie jest spontaniczne, tam działa się

${ }^{13}$ Farini do Cavoura, Teano 27 X 1860 r., [w:] La liberazione del Mezzogiorno e la formazione del Regno d'Italia. Carteggi di Camillo Cavour con Villamarina, Scialoja, Cordova, Farini, ecc., t. III, Bologna 1952, s. 208.

${ }^{14}$ Pantaleoni do Cavoura, Rzym 6 XI 1860 r., [w:] La questione romana negli anni 1860-1861. Carteggio del conte Cavour con D. Pantaleoni, C. Passaglia, O. Vimercati, t. I, Bologna 1929, s. 70.

${ }^{15}$ D’Azeglio do Pantaleoniego, Turyn 17 X 1860 r., [w:] Massimo d'Azeglio e Diomede Pantaleoni. Carteggio inedito, red. G. Faldella, L. Roux i C., Torino 1888, s. 430.

${ }^{16}$ Borromeo do Riccardiego di Netro, Turyn 14 XII 1860 r., [w:] La liberazione del Mezzogiorno..., t. IV, s. 71-72. 
przez egoizm; na Północy się myśli, na Południu się podskakuje; [...] w północnych Włoszech jest wychowanie cywilne, w południowych publiczna korupcja"17.

Wreszcie przykład dyskryminacji rasowej: „Populacja neapolitańska - zauważa generał Paolo Solaroli - jest najgorsza, jaką widziałem w Europie po mieszkańcach Porto, ale przewyższa ją $\mathrm{w}$ niemocy i w występku, w plugastwie. Nikt nie chce pracować, znaczna część żyje $z$ jałmużny przez czyste lenistwo, klasa robotnicza pracuje $z$ jedną trzecią naszej wydajności. [...] Korupcja zarówno wśród mężczyzn, jak i wśród kobiet przekracza wszelkie granice [...]. Zdobyliśmy tak bardzo złą krainę, że wydaje się aż niemożliwe, że w miejscu, gdzie natura zrobiła tak wiele dla terenu, mógł zrodzić się taki lud"18.

W ten sposób zaczęły się urzeczywistniać stereotypy i uprzedzenia, które sprawiły, że stosunki między Północą i Południem zawsze będa problematyczne. Południe jest postrzegane jako miejsce słabo rozwinięte (nie tylko gospodarczo); kula u nogi, perwersyjny sojusz mafii i polityki, plaga, za którą niesie się ryzyko rozprzestrzenienia i zakażenia reszty kraju, a także region, który pochłania fundusze Północy.

\section{Poza mitem: podział Północ-Południe z punktu widzenia statystyki}

Jak jednak sprawy wyglądają naprawdę? Czy naprawdę to „odmienność" strukturalna Południa zrodziła stereotypy o nierównomiernym rozwoju kraju w ciagu 150 lat, czy jest to może kwestia bardziej złożona, a odpowiedzialności za tę „anomalię" narodową Włoch powinno się szukać gdzie indziej, lub powinno się chociażby podzielić ją równo między Północ i Południe?

Trzeba od razu wyjaśnić, że przez przynajmniej 30 lat po zjednoczeniu włoskim rządom brakowało chęci konstruktywnego zmierzenia się $z$ problemami Południa. Włochy południowe stanowiły w znacznej części terytorium podbite militarnie, które musiało się uginać woli i interesom „racji stanu”: były antypaństwem w stosunku do

\footnotetext{
${ }^{17}$ Sorrentino do Nigry, Neapol 9 II 1861 r., [w:] ibidem, s. 288.

${ }^{18}$ Z Pamiętników Solaroliego (aneks V), [w:] ibidem, t. V, s. 231-232. O szczególnym spojrzeniu północnych „konkwistadorów” na Południe można przeczytać w eseju N els o na Mo go, "Altro che Italia!”. Il Sud dei piemontesi (1860-1861), „Meridiana. Rivista di storia e scienze sociali” 1992, no. 15, s. 53-89. Więcej o wypaczonym obrazie Południa także u tego samego autora w: Un paradiso abitato da diavoli. Identità nazionale e immagini del Mezzogiorno, Napoli 2004.
} 
państwa, światem brygantów, uchylających się od obowiązku wojskowego, niewykształconych, wreszcie swego rodzaju wewnętrzna „kolonią”, która musiała być zarządzana żelazną ręka przez okresowe stany oblężenia i specjalne prawa powierzone sądom wojennym.

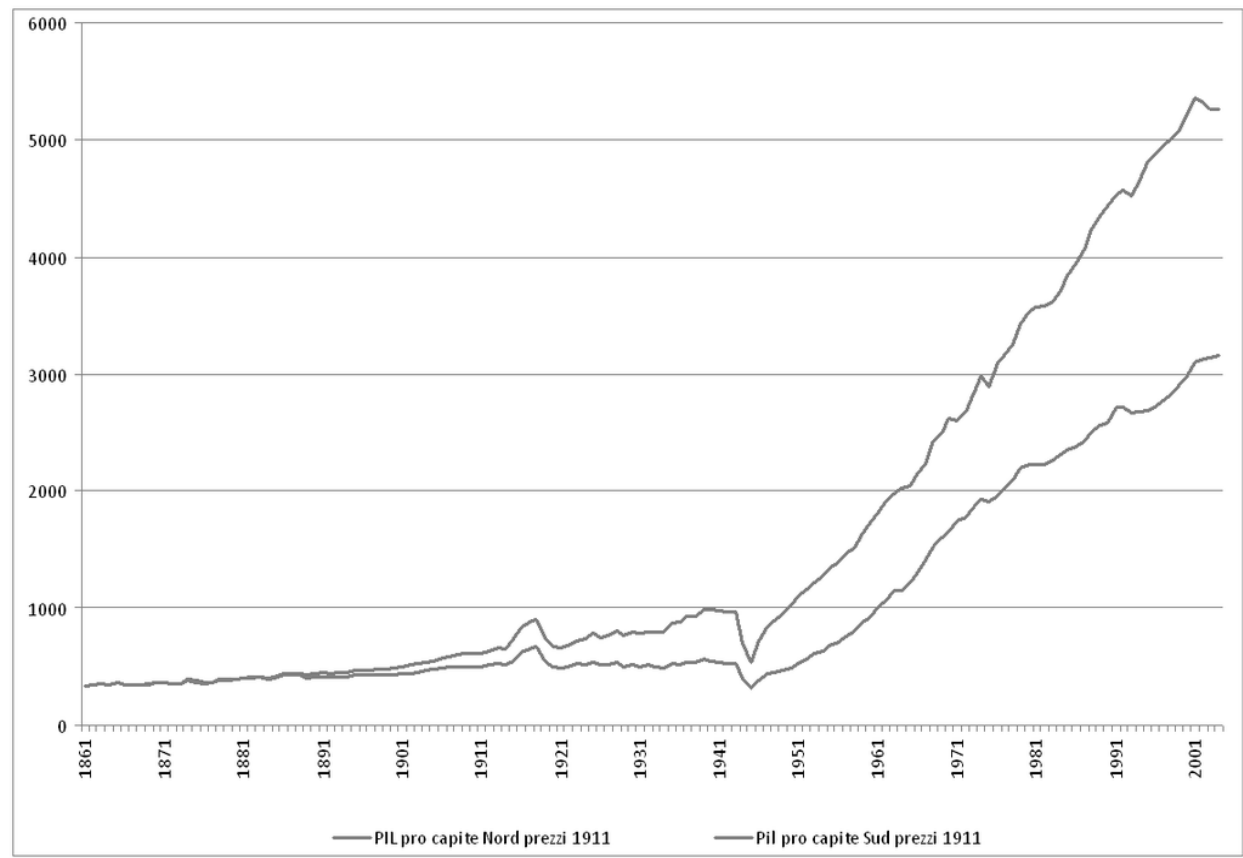

Wykres 1. Produkt krajowy brutto per capita we Włoszech (1861-2001)

Należy dodać, że w świetle obiektywnej analizy ekonomicznej nie obowiąuje kłamstwo czy półprawda o atawistycznie zapóźnionym Południu. $Z$ danych gromadzonych przez lata przez Narodowy Instytut Statystyczny, zlecanych przez Narodową Radę Badań Naukowych, ale także informacji dostarczanych przez Bank Włoch i innych obserwatorów ekonomicznych wynika, że w 1861 r. produkt krajowy brutto dwóch makroobszarów Włoch był dość podobny. Dzisiaj natomiast, po 150 latach, PKB Południa równa się jedynie 59\% PKB obszaru północno-środkowych Włoch (por. wykres 1)! ${ }^{19}$ Liczba przedsiębiorstw przemysłowych na południu nie różniła się znaczacco od ich liczby na północy kraju, chociaż inny był ich rodzaj (przemysł stoczniowy, wydobywczy i rolno-spożywczy).

${ }_{19}$ V. Daniele, P. Malanima, Il prodotto delle regioni e il divario Nord-Sud in Italia (1861-2004), „Rivista di Politica Economica”, marzec-kwiecień 2007, aneks, tab. 4. 
Należy doprecyzować, że na poziomie finansowym dawne państwo burbońskie, w przeciwieństwie do tego, co można byłoby sądzić, w 1860 r. wcale nie było w kryzysie: dobra państwowe i kościelne stanowiły niezmierne bogactwa, dużo większe niż w innych państwach włoskich; podatki były niskie, a dług publiczny o jedna czwarta niższy niż w Piemoncie. Wszystko to pozwala lepiej zrozumieć, jaki procentowo był wkład Południa w momencie utworzenia się skarbu nowego zjednoczonego państwa: stosunek, który został obliczony na mniej więcej dwie trzecie ${ }^{20}$. To bogactwo, co nigdy nie zostało wystarczająco podkreślone, w znacznej części posłużyło do pokrycia gigantycznego deficytu finansowego dawnego Królestwa Sardynii, którego dług publiczny, spowodowany prowadzonymi $\mathrm{w}$ poprzednim dziesięcioleciu wojnami, wzrósł w okresie poprzedzającym zjednoczenie o $500 \%{ }^{21}$.

Sytuacja zmieniła się radykalnie 15 lat później, wraz z protekcjonistycznym zwrotem roku 1876 i wielkim rozwojem przemysłowym trójkąta Mediolan-Turyn-Genua, silnie wspieranym przez państwo i inwestycje zagraniczne. Od tego momentu Południu nie udawało się dotrzymać Północy kroku. Dane potwierdzają ten obraz. Rozpocznijmy od statystyk związanych z ludnością: w 1861 r. zjednoczone Włochy liczyły 22,2 mln mieszkańców, spośród których 9 pochodziło $z$ dawnego Królestwa Obojga Sycylii (2,4 mln w Sycylii, która stanowiła trzeci pod względem liczby ludności region Włoch, na równi $z$ Kampanią oraz po Lombardii - 3,3 mln i Piemoncie 2,8 mln). Rytm wzrostu demograficznego wzrastał przez pierwsze 50-lecie, doprowadzając populację włoską do osiagnięcia liczby 36 mln mieszkańców w 1911 r., z czego Południe zamieszkiwało łącznie 13,5 mln, a Sycylię 3,8 mln. Dzięki temu, mimo trwałej fali migracyjnej, stała się ona drugim najliczniej zaludnionym regionem po Lombardii $(4,9 \mathrm{mln})^{22}$.

${ }^{20}$ Tak wynika chociażby $z$ danych przekazanych przez byłego ministra i doradcę państwa neapolitańskiego na podstawie źródeł oficjalnych. Por. G. Savare s e, Le finanze napoletane e le finanze piemontesi dal 1848 al 1860, Napoli 1862, s. 23-24. O silnych nierównościach powstałych na szkodę Południa w procesie formowania się budżetu państwa informuje także 50 lat po zjednoczeniu analiza Frances ca $\mathrm{S}$. Nitti e go, Nord e Sud. Prime linee di una inchiesta sulla ripartizione territoriale delle entrate e delle spese dello Stato in Italia, Torino 1900.

${ }^{21}$ Por. M. Lo n go, Nord „padre” del debito pubblico, „Il Sole 24 Ore”, 17 III 2011.

22 Por. Sommario di statistiche storiche dell'Italia 1861-1975, Roma 1976, tab. 3, s. 11 ; tab. 6 , s. 13 . 
Najbardziej interesujacce sa jednak następujące dane: po zjednoczeniu tylko 10 miast zamieszkiwało ponad 100 tys. mieszkańców, a dwa spośród nich, Palermo i Messyna, znajdowały się na Sycylii (pozostałe metropolie to: Neapol, Mediolan, Genua, Rzym, Turyn, Wenecja, Florencja, Bolonia). Dwadzieścia lat później sytuacja była zupełnie inna, ponieważ rytm rozwoju tych wielkich ośrodków miejskich stał się nierówny: bardzo intensywny w obszarze północno-zachodnim, umiarkowany w centrum, niski na południu. To kolejny znak kryzysu gospodarczego, który trapi Południe, na którym nie dostrzegano perspektyw i z którego raczej się emigrowało $^{23}$. W tym samym czasie w zawrotnym tempie powstały ośrodki miejskie związane $z$ wielkimi inwestycjami przemysłowymi w centrum i na północy. $Z$ początkowego prymatu Południa w handlu portowym i przemyśle stoczniowym 20 lat później zostało niewiele. Interwencja państwa zwróciła się ku innym gałęziom przemysłu, a pierwszeństwo w przemyśle stoczniowym przesunęło się ku północnemu centrum (Livorno, Genua, La Spezia). Wywołało to przewidywane negatywne konsekwencje w południowym aparacie produkcyjnym, który nie uniknął kryzysu.

To czytelny znak strategii modernizacji i rozwoju, która wykluczyła, czy też silnie ograniczyła, możliwości średniej wielkości ośrodków miejskich na południu (nieliczne wyjątki to Katania, Bari i Taranto) na rzecz ośrodków północno-centralnych. Na osobny tekst zasługuje zreszta wzrost liczby populacji Florencji, a przede wszystkim Rzymu w imię tworzenia gęstej siatki biurokratycznej urzędów oraz instytucji publicznych, związanych $z$ pełnieniem funkcji stolicy przez te dwa miasta: pierwsze między 1864 a 1870 r., drugie - po wspomnianej aneksji w roku 1870.

\section{Kwestie społeczne: brak reformy rolnej i niedostatek infra- struktury, emigracja, analfabetyzm}

Jednym $z$ efektów zmniejszonych możliwości produkcyjnych Południa, a co więcej, braku jakiejkolwiek reformy rolnej, która zmieniłaby tradycyjne relacje władzy na wsiach założonych na latyfundiach, był, jak wiadomo, początek wielkiej, ciagłej fali migracyjnej $z$ odległych regionów Włoch, która została uznana przez klasę rządzącą i znaczną część mieszczańskiej prasy tego okresu jako

${ }^{23}$ Por. G. Mo ntroni, La società italiana dall'unificazione alla Grande Guerra, Roma-Bari 2002, s. 10-11. 
„wentyl bezpieczeństwa”, konieczny w kraju usiłującym zainicjować szybki proces modernizacji. Ta fala stanowiła exodus populacji o rozmiarach biblijnych, przede wszystkim osób z Południa. Tylko w okresie 1900-1915 doprowadził on $4 \mathrm{mln}$ osób do opuszczenia południa kraju (ale także niektórych obszarów północnego wschodu Włoch) w poszukiwaniu pracy i lepszych warunków życia w odległych rejonach, takich jak obie Ameryki i Australia (por. tabele 1 i 2$)^{24}$.

Tabela 1

Emigracja włoska 1871-1915 (w mln)

\begin{tabular}{|c|c|c|c|c|}
\hline & $\begin{array}{c}Z \text { Włoch } \\
\text { północno- } \\
\text {-środkowych }\end{array}$ & $\begin{array}{c}\text { Z Włoch } \\
\text { południowych }\end{array}$ & Łacznie & $\begin{array}{c}\% \text { całkowitej } \\
\text { populacji }\end{array}$ \\
\hline $1876-1900$ & 3,724 & 1,534 & 5,258 & $16,1 \%$ \\
\hline $1901-1915$ & 4,621 & 4,149 & 8,770 & $24,3 \%$ \\
\hline $1876-1915$ & 8,345 & 5,683 & 14,028 & \\
\hline
\end{tabular}

Tabela 2

Pochodzenie według regionów (w $\mathrm{mln}$ )

\begin{tabular}{|l|c|c|c|}
\hline & $1876-1900$ & $1901-1915$ & Lacznie \\
\hline $\begin{array}{l}\text { Wenecja } \\
\text { Euganejska }\end{array}$ & 0,941 & 0,882 & 1,823 \\
\hline Piemont & 0,709 & 0,831 & 1,540 \\
\hline Kampania & 0,521 & 0,955 & 1,476 \\
\hline $\begin{array}{l}\text { Friuli i Wenecja } \\
\text { Julijska }\end{array}$ & 0,847 & 0,561 & 1,408 \\
\hline Sycylia & 0,226 & 1,127 & 1,353 \\
\hline Lombardia & 0,519 & 0,824 & 1,343 \\
\hline
\end{tabular}

${ }^{24}$ Por. Un secolo di emigrazione italiana 1876-1976, red. G. Rosoli, Roma 1978, s. 356-364. Opracowanie danych według autora. 
Inny ciekawy miernik oceny stopniowego oddzielania się Południa od reszty kraju można dostrzec w nierównomiernym rozwoju krajowej sieci połączeń drogowych i kolejowych. Rozwój krajowej sieci drogowej wydaje się bardzo niski w porównaniu do innych krajów europejskich, np. Francji $\left(0,3 \mathrm{~km} / \mathrm{km}^{2} \mathrm{w}\right.$ porównaniu do $\left.1,23 \mathrm{~km} / \mathrm{km}^{2}\right)$, a nie można o nim mówić niemal w ogóle, jeśli weźmiemy pod uwage południe Włoch $\left(0,1 \mathrm{~km} / \mathrm{km}^{2}\right)^{25}$. Sieć kolejowa całego państwa, która w okresie 1861-1914 jawi się ogólnie jako mało rozwinięta w stosunku do uprzemysłowionej Europy, także ukazuje sytuację wyraźnego podziału między północą a południem kraju. Prywatne spółki osiagnęły koniec Półwyspu dopiero pod koniec XIX w., a sytuacja nie poprawiła się nawet po stworzeniu jednej narodowej kompanii kolejowej w 1904 r. ${ }^{26}$ Należy zauważyć, że te niedostatki infrastrukturalne przetrwały 155 lat istnienia państwa włoskiego (większa część sieci kolejowej na Sycylii aż po dziś jest jednotorowa).

Jeżeli jednak istnieje jakiś element, który już na wstępie pokazuje wyraźna różnicę między Północą a Południem w roku 1861, to jest nim wskaźnik alfabetyzacji i w konsekwencji średni poziom wykształcenia ludności. Dane ${ }^{27}$ pokazuja dość mierny obraz całego kraju w stosunku do średniej Europy Zachodniej ${ }^{28}$. Obraz ten staje się jednak dramatyczny, jeśli prześledzimy dane odnoszące się do regionów południowych i wyspiarskich.

W momencie zjednoczenia (1861) krajowa średnia analfabetyzmu osiagnęła przerażający poziom 78\%. Pięćdziesiąt lat później (1911) wskaźnik spadł do „jedynie” 47\%, a po kolejnych 50 latach, w 1961 r., do 8,3\% ${ }^{29}$. Ci, którzy potrafili czytać i pisać, w pierwszej

${ }^{25}$ Por. G. Montroni, op. cit., s. 7.

${ }^{26}$ Ibidem.

${ }^{27}$ Chodzi o niepodważalne dane, znane dzięki szczegółowym badaniom sprzed pół wieku i uznawane od tej pory za kamienie milowe w tym temacie. Spośród nich ograniczymy się do zacytowania fundamentalnej pracy Tullia De Mauro, Storia linguistica dell'Italia unita, Roma-Bari 2001. Pierwsze wydanie tomu zostało opublikowane w 1963 r.

${ }^{28}$ W 1890 r., w przedziale wiekowym 11-40 lat, średnia (mężczyźni i kobiety) analfabetów we Włoszech sięgała $57 \%$ i była podobna do średniej w Hiszpanii (56\%), niższa niż w carskiej Rosji (68\%), ale zdecydowanie wyższa od średniej w Cesarstwie Austro-Węgierskim (26\%), w którym ponadto były regiony (Czechy, Morawy, Śląsk), gdzie analfabeci stanowili jedynie 3\% populacji w tym przedziale wiekowym. Por. S. Gu a r ra ci n o, P. Or toleva, M. Revelli, L'età delle rivoluzioni e l'Ottocento, Milano 1998, s. 655.

${ }^{29}$ Por. ibidem, s. 95, a także Grado di istruzione. Censimenti 1951-2001, Badania statystyczne Vincenza D’Aprile na podstawie źródeł Narodowego Instytutu 
dekadzie po zjednoczeniu stanowili nie więcej niż 2,5\% łącznej populacji (600 tys. na $22 \mathrm{mln}$ ); jeszcze mniej było tych, którzy mieli wykształcenie ponadpodstawowe $(0,9 \%)$. Po raz kolejny jednak dane $z$ różnych regionów pokazuja obraz Włoch „zjednoczonych” (i kulturalnie jednorodnych) jedynie na mapie i oficjalnych ogłoszeniach. O ile w 1861 r. w Piemoncie i Lombardii liczba analfabetów wynosiła 54\%, w regionach południowych ten wskaźnik oscylował między 86 a 89\%. Nawet w papieskim jeszcze Rzymie i na byłych terytoriach Państwa Kościelnego nie było dużo lepiej (68-84\%). W roku 1911 średnie te spadły, ale wciąż północny wschód (11-17\%) i północny zachód (25-29\%) znacząco różniły się od centrum (33-51\%) i od Południa (58-70\%). Po II wojnie światowej, w 1951 r., podział znacznie malał, ale o ile analfabetyzm na Północy prawie znikną (3-7\%) i znacznie zmniejszył się w centrum (10-14\%), to na Południu oscylował między 24\% (Kampania i Sycylia) i 32\% (Kalabria). Oznacza to, że ogromna liczba analfabetów - wciaż 3,8 mln Włochów w 1961 r. - skupiała się prawie wyłącznie na południu Włoch $(67,6 \% \mathrm{w} \text { porównaniu do } 14,3 \% \text { na Północy })^{30}$. Trzeba było poczekać ponad wiek od utworzenia się zjednoczonego państwa, by uznać plagę analfabetyzmu za pokonaną. Stało się to dzięki wielkiej reformie szkolnictwa, która po $1962 \mathrm{r}$. podniosła wiek obowiąkkowej edukacji szkolnej do 14 roku życia ${ }^{31}$.

$\mathrm{Na}$ osobna dyskusję zasługuje rzeczywista sytuacja językowa zjednoczonych Włoch, którą tylko krótko nakreślę. Chodzi o trudności we wprowadzeniu (i narzuceniu) języka włoskiego w kraju, który obfitował w ogromną liczbę dialektów regionalnych (w niektórych

Statystyki (ISTAT), http://www.edscuola.it/archivio/statistiche/analfabetismo. pdf, tab. 24, s. 26. W tym temacie por. także G. Ge nove si, Storia della scuola in Italia dal Settecento a oggi, Roma-Bari 2010.

${ }^{30}$ Por. T. De Mauro, op. cit., s. 94-101. Neapol w tym kontekście stanowi najbardziej jaskrawy przykład sprzeczności Włoch w chwili zjednoczenia: jest najgęściej zaludnionym miastem (ponad 450 tys. mieszkańców), znajduje się w nim największy uniwersytet w kraju i ma najwyższy wskaźnik analfabetyzmu spośród wielkich miast. Między 1874 a 1901 r. w Neapolu wskaźnik ten spadł jedynie z 65 do $50 \%$, podczas gdy w tym samym okresie inne wielkie miasta poczynia w tym zakresie wielkie postępy: w Mediolanie liczba analfabetów spadła z 23 do 19\%, w Turynie z 33 do 16\%, w Genui z 40 do 25\%, we Florencji z 40 do 27\%, w Bolonii z 47 do 28\%, w Rzymie z 52 do 30\%. Por. G. Montroni, op. cit., s. 20.

${ }^{31}$ Reforma ujednoliciła szkoły średnie (VI-VIII klasa), kładac kres anachronicznej dyskryminacji społecznej, wynikającej ze zróżnicowania na ten typ szkolnictwa i tak zwana „Szkołę przysposobienia do zawodu”. Ustawa (nr 1859) została przyjęta 31 XII 1962 r. 
przypadkach były to tak naprawdę języki, np. friulski i sardyński). Było to najważniejsze zwierciadło, w którym odbijały się podziały kulturowe Włoch istniejace i utrzymujące się w czasie nie tylko na poziomie regionów, lecz także na poziomie klas społecznych. Można stwierdzić, że akceptowalna jedność językowa weszła w życie dopiero w niedawnych czasach dzięki podwyższeniu się poziomu edukacji podstawowej, ale przede wszystkim dzięki rozprzestrzenieniu się na masowa skalę przekazu telewizyjnego ${ }^{32}$.

Ostatni, równie ważny jak poprzednie czynnik, który chciałbym przedstawić, wiąże się $z$ poziomem udziału obywateli w życiu publicznym, w szczególności $z$ wykorzystywaniem prawa głosu. Udział ten od początku był uwarunkowany negatywnie przez dwie kwestie: po pierwsze, system wyborczy aż do 1913 r. pozostawal niezwykle ograniczony pod względem klasowym; druga przyczyna to, jak zwykle ją określam, strukturalna „anomalia” współczesnych Włoch, czyli „obecność” innego państwa (Państwa Kościelnego) wewnattrz czy też obok państwa włoskiego. O ile pierwsza przeszkoda została oczywiście pokonana w trakcie 150 lat zjednoczonych Włoch, o tyle drugi czynnik wciąż - niezależnie od osądu, pozytywnego czy negatywnego - istnieje i funkcjonuje w życiu kraju.

Statystyki mówią nam, że w pierwszym 50-leciu Włosi uczestniczyli w głosowaniu w bardzo nikłym stopniu $z$ powodu systemu wyborczego ściśle powiązanego $z$ cenzusem, który wykluczał całe grupy społeczne (chłopów i robotników, analfabetów), nieosiagające minimalnego wymaganego dochodu. Między 1861 a $1880 \mathrm{r}$. liczba osób mających prawo głosu wahała się między 1,9 a 2,2\% ludności (400-600 tys. głosujących na 24 mln mieszkańców). Dane te staja się jeszcze bardziej negatywne, jeśli weźmiemy pod uwage wysoki procent głosów wstrzymujących się (wyższy na Północy niż na Południu), który w praktyce zmniejsza o połowę liczbę głosujących. Po reformie wyborczej z 1882 r. (minimalny wiek zmniejszony z 25 do 21 lat i obniżenie o połowę wymaganego poziomu wniesionych podatków bezpośrednich) liczba wyborców osiąnęła około

${ }^{32}$ Kluczowe znaczenie $z$ tej perspektywy miała akcja wspomagania edukacji dokonywana przez telewizję publiczna za pomoca kursów na poziomie podstawowym i średnim, transmitowanych rano i w godzinach wieczornych i odbieranych przez specjalnie zorganizowane grupy słuchaczy nawet w najmniejszych ośrodkach wiejskich kraju. Najbardziej znaczacca w historii była zwłaszcza rola odegrana przez dwie audycje telewizyjne tych lat: Telescuola (1958-1966) oraz Non è mai troppo tardi. Corso di istruzione popolare per il recupero dell'adulto analfabeta (1960-1968). 
2 mln osób (mniej więcej jedna czwarta dorosłej męskiej populacji). Włochy pozostawali jednak w tyle w stosunku do innych dużych krajów Europy Zachodniej (7-9\% ludności przeciw 20\% w Niemczech i Francji) ${ }^{33}$.

Interesujaca informację, która pozwala jeszcze lepiej zrozumieć podstawową różnicę między Północą a Południem kraju, przynoszą nam różne preferencje wyborcze $\mathrm{w}$ tych dwóch makroregionach. W sposób jedynie pozornie niewytłumaczalny zauważa się, że już w 30-leciu 1876-1904 Południe było bardziej konserwatywne i prorządowe (46-48\%) w porównaniu do Północy (37-35\%) i centrum (17\%), podczas gdy republikańska opozycja, radykalna i socjalistyczna, otrzymywała większe poparcie na Północy (57\%) niż na Południu $(26 \%)^{34}$. Ten trend wyborczy nie zmienił się nigdy: nawet po wprowadzeniu powszechnego prawa wyborczego dla mężczyzn (1913), po zakończeniu I wojny światowej (przyjęcie proporcjonalnego systemu wyborczego w 1919 r.), a nawet w chwili zrodzenia się Republiki w 1946 r., kiedy wyniki referendum w sprawie ustroju państwa (republika 54,3\% - monarchia 45,7\%) pokazały, że Południe wolało monarchię od republiki (64,4\%), podczas gdy Północ popierała republikę przeciwko monarchii $(66,8 \%)^{35}$. W jaki sposób to wytłumaczyć? Odpowiedź byłaby bardzo długa, ale ujmując sprawę jednym zdaniem, nie można nie odnieść się tu do nie zawsze czystych metod, którymi partie rządowe usiłowały zawsze zdobyć poparcie na Południu.

$\mathrm{Na}$ niskim stopniu udziału w wyborach (średnia zawsze około 43\% majacych prawo głosu w 17 wyborach parlamentarnych od 1861 do 1913 r.) mocno zaważyło weto narzucone na katolików - zatem na wszystkich Włochów - przez papieża Piusa IX w jego słynnej bulli Non expedit („Nie należy” z 1874 r.) ${ }^{36}$, formie głuchego protestu przeciwko przyłączeniu Rzymu do Włoch sprzed czterech lat ${ }^{37}$,

${ }^{33}$ Por. E. Rotelli, Le istituzioni politiche e amministrative, [w:] Storia della società italiana, t. XIV (Il blocco di potere nell'Italia unita), Milano 1980, s. 362-363, 371-372.

${ }^{34}$ Por. ibidem, s. 373.

${ }^{35}$ Por. M.S. Piretti, Le elezioni politiche in Italia dal 1848 a oggi, Roma-Bari 1996, s. 418-424, 343.

${ }^{36}$ Chodzi w szczególności o Dyspozycję Penitencjarii Apostolskiej, która we wrześniu 1874 r. deklarowała, że udział włoskich katolików w wyborach i w ogóle w życiu politycznym jest nieakceptowalny. Dyspozycja została uchylona oficjalnie dopiero w 1919 r.

37 Było ono możliwe wskutek klęski Napoleona III w wojnie francusko-pruskiej i wynikającego z niej upadku Drugiego Cesarstwa. Dzięki temu Włochy 
i wynikającego $z$ niego końca jego świeckiej władzy. Weto zostało później usunięte, ale niekorzystne rezultaty ponad pół wieku sporów między państwem a Kościołem, aż do konkordatu między Stolica Apostolska a reżimem faszystowskim w lutym 1929 r. ${ }^{38}$, wywołały trwałe efekty we włoskim społeczeństwie, przyczyniajac się znacznie do pogłębienia istniejącego już podziału na poziomie gospodarczym, społecznym i kulturowym. Konsekwencje tego podziału, oczywiście nie w tak wyraźny sposób, są odczuwane do dziś.

Jedna rzecz jest pewna: państwo włoskie poza symbolicznym zwycięstwem nie odniosło wielkich korzyści ze wspomnianego przyłączenia Rzymu w 1870 r. W zasadzie nie udało się znieść czy zmniejszyć pewnych prerogatyw Watykanu oraz jego bezdyskusyjnego, choć niebezpośredniego wpływu na polityczne i społeczne losy kraju. Jednocześnie na mocy zasady Cavoura „wolny Kościół w wolnym państwie” udzielono Państwu Kościelnemu szerokich gwarancji terytorialnych i finansowych (m.in. roczne swiadczenie w wysokości 3,2 mln lirów, odpowiadajace aktualnej kwocie 15 mln euro) ${ }^{39}$. W rzeczywistości Watykan, przez swój bezdyskusyjny wpływ duchowy i zdolność do zawierania „sojuszy” z częścia klas rzadzacych gospodarką i finansami w Włoszech i poza nimi, zdołał w krótkim czasie „odzyskać” Rzym i tradycyjną rolę głównej

nie były już związane układami włosko-francuskimi z 1864 r. (tzw. konwencja wrześniowa), na mocy której strona włoska zrezygnowała ze wszelkich roszczeń terytorialnych w stosunku do Rzymu, dając jednocześnie Państwu Kościelnemu gwarancję wycofania się z planów ewentualnych ataków zewnętrznych (pośrednia konsekwencja paktu było przeniesienie stolicy z Turynu do Florencji).

${ }^{38}$ Chodzi o tzw. ugodę między państwem włoskim a Stolicą Apostolska, która nastąpiła dzięki zawarciu traktatów laterańskich, podpisanych 11 II 1929 r. przez szefa rządu włoskiego, Benita Mussoliniego i watykańskiego sekretarza, kardynała Pietra Gasparriego. W aneksie Konkordat zostały zdefiniowane i uregulowane stosunki cywilne i religijne we Włoszech. Konkordat został poddany rewizji i modyfikacjom w lutym 1984 r. i w tej nowej formie jest do tej pory wiążący.

${ }^{39}$ Ustawa nr 214, tzw. ustawa dla zagwarantowania prerogatyw Ojca Świętego, przyjęta przez włoski parlament $13 \mathrm{~V} 1871$ r., przewidywała jednostronnie, poza zacytowanym corocznym świadczeniem, poszanowanie nienaruszalności i obronę papieża, prawo do reprezentacji dyplomatycznej i możliwość posiadania pozaterytorialnych pałaców i posiadłości w Rzymie i okolicach. Klerowi przyznano absolutna wolność sprawowania kultu oraz prawo do zgromadzeń i przemieszczania się w obrębie Królestwa Włoch. Odpowiedzią Piusa IX, który określił przyznane odstępstwa jako „błahe przywileje i prawa”, był natychmiastowy protest przeciwko niezgodzie na uznanie jego władzy świeckiej (encyklika Ubi Nos z 15 V 1871 r.) i kilka lat później wspomniana bulla Non expedit. 
postaci w społeczeństwie włoskim w sposób dużo bardziej znaczący i warunkujący niż w innych katolickich państwach Europy.

\section{Wnioski}

Włosi w XX w. bez watpienia poczynili znaczace kroki na drodze do budowy powszechnie podzielanego poczucia jedności narodowej. Stało się to także dzięki dramatycznym doświadczeniom historycznym: I wojnie światowej, w której zginęło ponad 600 tys. osób (z Północy i Południa); 20-leciu faszyzmu, dyktatury, która demagogicznie opierała się na silnie podkreślanej retoryce patriotycznej; walce $z$ nazi-faszyzmem i jej wysokim walorom demokratycznym. Dziś jednak, po kilku dekadach dobrobytu, Włosi znów zaczynaja dzielić się w wielu sprawach i spoglądać na siebie $z$ pewna podejrzliwością, także $z$ powodu trudnego do przezwyciężenia kryzysu gospodarczego.

„Kwestia poludniowa"40, czyli podstawowy problem strukturalny, z którym musiały się mierzyć wszystkie rządy w ciągu 150 lat i który wydawał się niemal bliski pozytywnemu zakończeniu 40 lat temu, nigdy nie została rozwiazana. W ostatnich 30 latach problem ten pogłębił się nawet przez obiektywne trudności, ale także przez niewattpliwą niemoc polityczna. Wystarczą tylko następujące alarmujące dane: bezrobocie wśród młodych (20-34 lata), którego średnia krajowa w roku 2015 wynosiła $27,6 \%$, na Południu osiagnęło $40,1 \%$, czyli dwa razy tyle, co na Północy $(19,6 \%)^{41}$. Dystans między Północa a Południem zatem znów rośnie, a Włosi z Północy, czy też

40 Tym terminem historiografia włoska określa ogólnie problemy zwiąane ze szczególną sytuacją trudności gospodarczych i społecznych, które naznaczyły od poczatku warunki na Południu w stosunku do reszty kraju. Poczawszy od lat siedemdziesiątych. XIX w., wywiązała się z nich jawna dyskusja, która wpływa na decyzje polityczne podejmowane przez kolejne rządy włoskie aż po dzisiejsze czasy. Pełne informacje o debacie wokół „kwestii południowej” znajduja się w wielu opracowaniach, m.in. w: F. B arbagallo, Mezzogiorno e questione meridionale (1860-1980), Napoli 1980; S. Cafiero, Questione meridionale e unità nazionale 1861-1995, Roma 1999, a także we wciąż aktualnym zbiorze myśli południowej Il Sud nella storia d'Italia. Antologia della questione meridionale, red. R. Villari, Roma-Bari 1978.

${ }^{41}$ Najnowsze dane przekazane przez ISTAT pokazują, że wskaźnik bezrobocia $\mathrm{w}$ tym i innych przedziałach wiekowych jest dziś o wiele bardziej niepokojący w porównaniu do okresu sprzed 25 lat, kiedy przy średniej krajowej 15,4\% bezrobocie wśród młodych na Południu sięgało 24,6\%, podczas gdy na Północy wynosiło 9,6\%. Por. http://dati.istat.it/Index.aspx?DataSetCode=DCCV_DISOCCUPT\&Lang=. 
może znaczna ich część, zaczęli znów odtwarzać stereotypy sprzed 150 lat: Południe jako hamulec rozwoju, okazja do marnotrawienia pieniędzy publicznych i odbiorcy źle rozdanych i jeszcze gorzej wydanych środków. Stąd bierze się wyrażane w parlamencie przez niektóre cieszace się szerokim poparciem na Północy i w północnym centrum $^{42}$ siły polityczne pragnienie oddzielenia losów i funduszy (funduszy tych Włoch, które pracuja na bogactwo kraju) od Włoch podrzędnych, zapóźnionych niewydajnych i, ogólnie rzecz biorąc, „przestępczych”. Sa to właściwie te same stereotypy, te same uprzedzenia, o których pisałem na początku.

Gorzko pokazały to obchody 150 rocznicy państwa włoskiego sprzed pięciu lat. Faktycznie: być może powodów ku temu, by żyć wspólnie pod jednym dachem, jest teraz mniej, a niechcący świadczy o tym rząd kraju. Panuje zupełnie inna sytuacja niż 55 lat temu, kiedy $z$ okazji stulecia włoskiego zjednoczenia rząd dokonał wielkich wysiłków propagandowych w celu promowania wartości jedności narodowej. Najpierw dzięki historycznym igrzyskom olimpijskim w Rzymie (1960), a później dzięki wielkiej wystawie w Turynie (1961) Włochy na kilka lat przybrały odświętne szaty, a duma $z$ przynależności do narodu włoskiego przekazywana była aż po najdalsze krańce kraju. Te czasy, niestety, wydają się bardzo odległe.

\section{Z języka włoskiego przełożyła Katarzyna KowaliK}

${ }^{42}$ Należy się tu odnieść przede wszystkim do Ligi Północnej, partii politycznej utworzonej pod koniec lat osiemdziesiątych, która stopniowo pochłaniała inne małe partie regionalne, takie jak Liga Wenecka, Autonomiczny Piemont, Unia Liguryjska i inne. Jej poparcie wyborcze, mimo że związane głównie $z$ obszarem północnym, relatywnie wzrosło w ostatnich latach także w centralnych regionach kraju, dajac partii w wyborach narodowych między 1996 a 2008 r. od 8 do 10,5\% głosów. W ostatnich wyborach z 2013 r. zdobyła nieco ponad 4\% głosów. O jej historii i konotacjach antropologiczno-kulturowych por. G. Pas salacqua, Il vento della Padania. Storia della Lega Nord 1984-2009, Milano 2009; L. De matteo, L'idiota in politica. Antropologia della Lega Nord, Milano 2011. 


\section{Bibliografia}

\section{Ź RÓDEA DRUKOWANE}

D’Azeglio M., I miei ricordi, nowa edycja krytyczna, red. A.M. Ghisalberti, Torino 1949.

Fare gli italiani. Scuola e cultura nell'Italia contemporanea, t. I, red. S. Soldani, G. Turi, Bologna 1993.

Il Sud nella storia d'Italia. Antologia della questione meridionale, red. R. Villari, Roma-Bari 1978.

La liberazione del Mezzogiorno e la formazione del Regno d'Italia. Carteggi di Camillo Cavour con Villamarina, Scialoja, Cordova, Farini, ecc., t. III, Bologna 1952.

La questione romana negli anni 1860-1861. Carteggio del conte Cavour con D. Pantaleoni, C. Passaglia, O. Vimercati, t. I, Bologna 1929.

Massimo d'Azeglio e Diomede Pantaleoni. Carteggio inedito, red. G. Faldello, L. Roux i C., Torino 1888.

Savarese G., Le finanze napoletane e le finanze piemontesi dal 1848 al 1860, Napoli 1862.

\section{Opracowania}

Banti A.M., La nazione del Risorgimento. Parentela, santità e onore alle origini dell'Italia unita, Torino 2000.

Barbagallo F., Mezzogiorno e questione meridionale (1860-1980), Napoli 1980.

Brignoli M., Massimo d'Azeglio. Una biografia politica, Milano 1988.

Cafagna L., Cavour, Bologna 1999.

Cafiero S., Questione meridionale e unità nazionale 1861-1995, Roma 1999.

D’Aprile V., Grado di istruzione. Italia, Regione Puglia, Provincia Bari e città di Bari e Conversano (BA). Indagine statistica, http://www.edscuola.it/archivio/statistiche/analfabetismo.pdf.

Daniele V., Malanima P., Il prodotto delle regioni e il divario Nord-Sud in Italia (1861-2004), „Rivista di Politica Economica”, marzec-kwiecień 2007.

De Mauro T., Storia linguistica dell'Italia unita, Roma-Bari 2001.

Dematteo L., L'idiota in politica. Antropologia della Lega Nord, Milano 2011.

Fornaro P., „Fatta l'Italia, bisogna fare gli italiani”. Elogio di una Nazione imperfetta, "Anuarul Institutului de studii italo-român” [Cluj-Napoca-Rzym] 2013, t. X, s. 259-279.

Genovesi G., Storia della scuola in Italia dal Settecento a oggi, Roma-Bari 2010.

Gioberti V., Del primato morale e civile degli italiani, Capolago 1844.

Gioberti V., Delle speranze d'Italia, Capolago 1844.

Guarracino S., Ortoleva P., Revelli M., L'età delle rivoluzioni e l'Ottocento, Milano 1998.

Hearder H., Cavour, London-New York 1994. 
Lepre A., Storia della Prima repubblica. L'Italia dal 1943 al 2003, Bologna 2006.

Longo M., Nord „padre” del debito pubblico, „Il Sole 24 Ore”, 17 III 2011.

Moe N., „Altro che Italia!”. Il Sud dei piemontesi (1860-1861), „Meridiana. Rivista di storia e scienze sociali" 1992, no. 15, s. 53-89.

Moe N., Un paradiso abitato da diavoli. Identità nazionale e immagini del Mezzogiorno, Napoli 2004.

Montroni G., La società italiana dall'unificazione alla Grande Guerra, Roma-Bari 2002.

Nitti F.S., Nord e Sud. Prime linee di una inchiesta sulla ripartizione territoriale delle entrate e delle spese dello Stato in Italia, Torino 1900.

Passalacqua G., Il vento della Padania. Storia della Lega Nord 1984-2009, Milano 2009.

Piretti M.S., Le elezioni politiche in Italia dal 1848 a oggi, Roma-Bari 1996.

Rotelli E., Le istituzioni politiche e amministrative, [w:] Storia della società italiana, t. XIV (Il blocco di potere nell'Italia unita), Milano 1980.

Sommario di statistiche storiche dell'Italia 1861-1975, Roma 1976.

Un secolo di emigrazione italiana 1876-1976, red. G. Rosoli, Roma 1978. 